\title{
PRACTICE OF ECONOMIC ANALYSIS METHODS IN RESEARCHES OF INFORMATION CONFRONTATION
}

\author{
G. Tsvetkova ${ }^{1}$, A. Eshpoldina ${ }^{2}$ \\ DOI: http://doi.org/10.15350/L_26/9/5
}

\begin{abstract}
The paper demonstrates the use of economic methods in researches of information confrontation of countries. The dynamics of population size and internet users growth in Russia and the United States is compared on the basis of horizontal analysis tools. Comparative analysis of the budget and costs structure on information confrontation, positioning of countries on key indicators of global competitiveness showed catch-up strategy of Russia's development.
\end{abstract}

Keywords: economic analysis, statistical methods, horizontal analysis, information confrontation, network warfare.

Nowadays, information confrontation of countries across the world is conducted at a qualitative level, and network warfare is one of forms of this confrontation. Network warfare is not only the area of geopolitics, it covers more wide range of involvement of different spheres, ranging from the military forces and the diplomatic channels, ending with information sphere, psychology and inner world of human. The economy and finances are acting as the object of information confrontation and cyber-attacks. It implies active use of economic tools in researches of given processes (Table 1).

Table 1

Technology of network warfare in the World economy

and International finance

\begin{tabular}{|c|l|}
\hline Purpose & Damage to economy, information dominance. \\
\hline $\begin{array}{c}\text { Opperations } \\
\text { (covert) }\end{array}$ & $\begin{array}{l}\text { Country's economy (monetary-policy tools and financial rela- } \\
\text { tions) }\end{array}$ \\
\hline Industrial espionage (access to sensitive information), specula- \\
$\begin{array}{c}\text { tive attacks, organization of wars, revolutions, "orange" sce- } \\
\text { nario, provocations, fraud, manipulations, trolling. }\end{array}$ \\
\hline Means & $\begin{array}{l}\text { Diplomatic channel - economic diplomacy, shadow effect } \\
\text { (opinions), direct effect (sanctions). }\end{array}$ \\
\hline $\begin{array}{l}\text { Mass media, Internet usage (twitter, Facebook, Google), cyber- } \\
\text { attacks, attacks from hackers, organization of financial and } \\
\text { trading systems failures, freezing of bank accounts. }\end{array}$ \\
\hline
\end{tabular}

Based on data from the article of Smirnov F.A. Network warfare in the world economy and international finance [7].

\footnotetext{
${ }^{1}$ Galina Tsvetkova, Candidate of Economic Sciences, Associate Professor Mari State University, Volga State University of Technology, Russia.

${ }^{2}$ Anastasia Eshpoldina, Master's student, Mari State University, Russia.
} 
Economic analysis tools are based on three main areas of knowledge: mathematics, statistics, and economics. Within this article we present examples of the statistical methods use in the research of information confrontation between the United States and Russia. Statistical methods are based on the average and relative values, the index method, correlation and regression analysis. The chain growth rates of the internet users number and the chain growth rates of population have been calculated to demonstrate the economic tools (Table 2).

Table 2

Growth rates (chain) of population and the internet users in Russia and the USA, 2008-2015,\%

\begin{tabular}{|l|c|c|c|c|c|c|c|c|}
\hline & $\mathbf{2 0 0 8}$ & $\mathbf{2 0 0 9}$ & $\mathbf{2 0 1 0}$ & $\mathbf{2 0 1 1}$ & $\mathbf{2 0 1 2}$ & $\mathbf{2 0 1 3}$ & $\mathbf{2 0 1 4}$ & $\mathbf{2 0 1 5}$ \\
\hline $\begin{array}{l}\text { Popu- } \\
\text { lation } \\
\text { size } \\
\text { of } \\
\text { Rus- } \\
\text { sia }\end{array}$ & 99,96 & 100,035 & 100,04 & 100,08 & 100,17 & 100,2 & 100,2 & 100,209 \\
\hline $\begin{array}{l}\text { Inter- } \\
\text { net } \\
\text { users } \\
\text { in } \\
\begin{array}{l}\text { Rus- } \\
\text { sia }\end{array}\end{array}$ & 108,8 & 108,09 & 148,28 & 113,95 & 130,2 & 106,53 & 103,75 & 104,09 \\
\hline $\begin{array}{l}\text { Popu- } \\
\text { lation } \\
\text { size } \\
\text { of the } \\
\text { USA }\end{array}$ & 100,95 & 100,88 & 100,84 & 100,76 & 100,77 & 100,74 & 100,78 & 100,79 \\
\hline $\begin{array}{l}\text { Inter- } \\
\text { net } \\
\text { users } \\
\text { in the } \\
\text { USA }\end{array}$ & 108,8 & 108,09 & 148,28 & 113,95 & 130,2 & 106,53 & 103,75 & 104,09 \\
\hline
\end{tabular}

Calculations based on data from The World Bank [8].

Statistical methods allow making a comparison of the investigated data and facts of the socio-economic life. It should be noted that the prerequisite for comparative analysis is a compatibility of compared indicators, involving: the unity of volume, cost, quality, structural indicators; the unity of the periods of time for which the comparison is made; compatibility of methodology for calculating indicators.

Practice of economic analysis tools in the researches of political processes allows to give the characteristics of main subjects of political processes, resources, methods and conditions of their interaction and also to give the logical sequence of this interaction. Furthermore, the political process factors, equilibrium level, space and time of its development can be identified as policy process parameters. An important aspect of political process analysis is the identification of its statistic and dynamic characteristics.

Economic methods give a "picture" of the political process at a particular time. Statistical representation about the political process parameters is typi- 
cal for economic analysis of political situation. Such analysis identifies a system of ties and relations between main elements of the political process, which was established by the particular moment. Thus, it forms a basis for comparison of several political situations, different during time. In other words it creates the basis for reveal of the political process dynamics (features of political change) [5].

The development analysis of political process is very essential for revealing of dynamic characteristics. Similar analysis can be carried out using tools developed in the framework of such scientific approach as analysis of political discourse. In addition, enough interesting results for representation the process dynamics gives the application of methods of formal modeling, game theory as well as theory of political decision-making [1, p.83].

Combination of statistical and dynamic approaches of analysis can be compared with the production process and viewing of the videotape. Every separate frame describes a particular situation. On base of the review of each separate frame, to some extent we can characterize the main actors, the nature and conditions of their interaction, etc. However, this analysis will be incomplete: it will be similar to the photo, devoid of dynamics and context. Only by viewing series of rapidly changing frames, we can provide a complete picture of the plot, dynamics and also the basic parameters of the ongoing process.

An important element in the study of the statistic and dynamic characteristics of political process is the analysis of its external environment, which includes social, economic, and cultural factors influencing the political process, as well as political change at higher levels.

Let's imagine an example of horizontal analysis. This analysis allows comparing the dynamics of dissimilar processes through growth rates.

Horizontal comparative analysis is applied to determine the absolute and relative deviations of the actual level of the studied parameters from the base deviation. The presented below graph of dynamics of Internet users number in China, UK, Germany, Russia and the United States for 1997-2015 demonstrates the level of the Internet usage in different regions (figure 1).

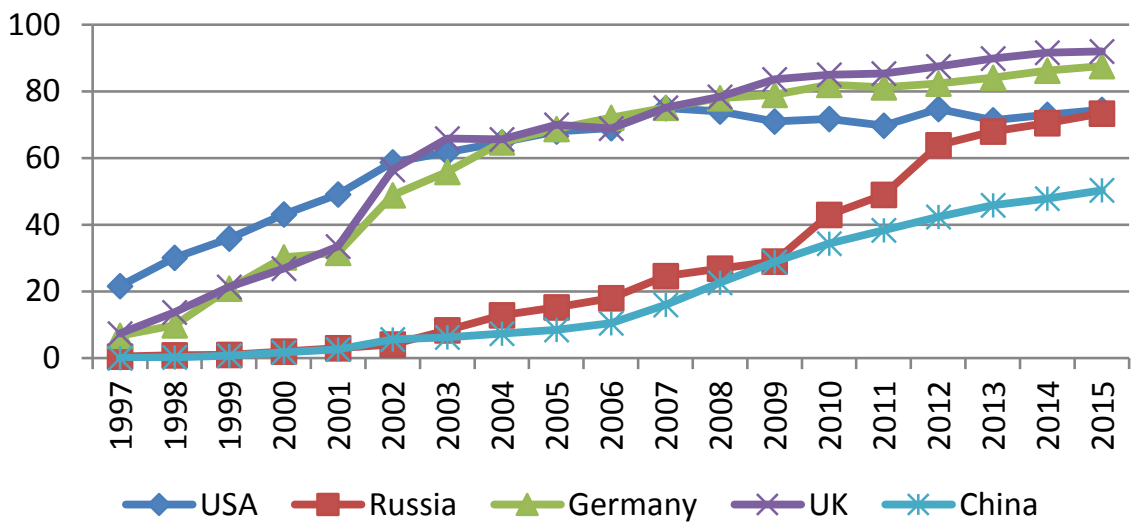

Figure 1. Dynamics of Internet users, 1997-2015, \%.

In 1997 the USA was the leader in the number of internet users. China is lagging behind in the number of Internet users compared with other countries. 
The UK became the leader by 2015 .

It should be noted that today there are about 4 billion internet users in the world, and it is particularly significant that the Internet has no limits and its possibilities are infinite. By no means all users understand which threats it carries and how the information security is implemented. The criminal use of information and communication technologies and its use for terrorist and military and political purposes is widely distributed. The further discussion of this important topic which affects the national security of the United States and Russia in the field of cyber security became impossible in connection with the sanctions against Russia [4, p.22].

Business is also a victim of cybercrime. There is not only increase in the number of attacks, but also a range of platforms which are exposed to this. If a few years ago the bulk of the attacks occurred at the corporate level, today there is an increasing tendency of attacks on private individuals. The malicious programs for smartphones help cybercriminals to get access to e-wallets and online banking systems that are connected to smartphones and tablets. Nearly half of all cyber-attacks are committed against such segment of economy as private individuals and small businesses, because they can't afford reliable protection against hackers [3, p.45].

Each Russian company loses \$ 3 million a year on average. The American companies suffer from cyber-attacks more than others. They lose more 12,5 million dollars in the course of year. The average figure around the world is less than $\$ 5.5$ million for organization over the same period [6].

Network warfare affects not only corporate interests but also national interests. Cyber-attacks were widely used against Ukraine during the conflict in the East of the country in 2014. Cybercriminals had applied different types of attacks: unauthorized bugging, radio intercepts, mobile spam during elections. The recent accusations against the Russian Federation concerning the attack on the data base of the Democratic party of the USA in the midst of the election campaign also raise the issue of information security [2].

In the study by means of horizontal analysis, it is possible to identify the dynamics of various processes characterizing the development of information confrontation in all its diversity. For example, a comparative analysis of growth rates in population size and of growth rates in the number of Internet users clearly demonstrates the excess of the latter indicator in 2008-2014 years that can be characterized as a positive trend (Figure 2).



Population Internet users

Figure 2. Growth rates (chain) of population and the Internet users in Russia, 2008-2015, \%. 
In general, horizontal analysis is a convenient research tool of the processes of information confrontation of the USA and Russia.

Vertical analysis allows us to investigate a whole part through its elements, and to determine the share of each structural element. Figures 3 and 4 show the share of $R \& D$ expenditure, investment in telecommunications and information security from the total GDP of the US and Russia in 2015. Analysis provides an opportunity to conclude that the share of Russian investments in information security from GDP exceeds the share of US investments in similar items of expenditure.

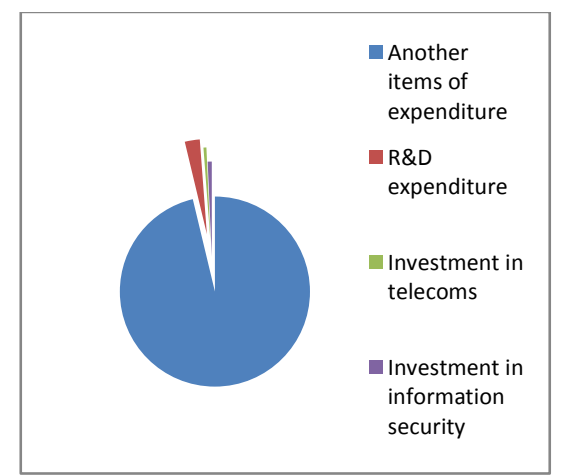

Figure 3. The US budget, 2015, \%.

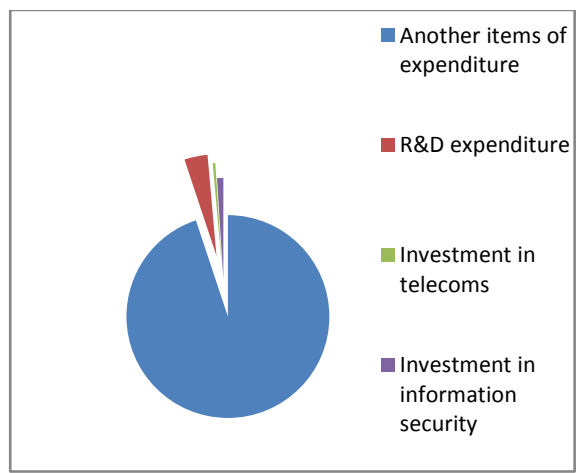

Figure 4. Russian budget, 2015, \%.

Methods of comparative analysis and perceptual maps are widely used in political researches. Perceptual map is a convenient way of visualizing the key characteristics of research objects. An individual case of perceptual map practice is "polygon of competitiveness". The method allows you to quickly analyze a country's competitiveness compared to key competitors.

In our example while constructing the polygon of competitiveness of the USA and Russia we used the following characteristics of country: level of prosperity, population size, Human Development Index, life expectancy, level of foreign direct investments, global competitiveness, Information and Communication Technology Development Index, level of Gross Domestic Product, Internet Development level, R\&D expenditure level. The open data of the following sites were used as research information base: The World Bank, International Monetary Fund, International Telecommunication Union, and Eurostat. The source indexes were converted to ten-point scale: where 1 is the lowest score and 10 is the highest. The next step is the polygon constructing on the basis of given estimates (Figure 5).

The polygon of competitiveness (perceptual map) makes possible to visually compare the parameters of Russia and the USA. Diagram shows the US dominance on many indicators (R\&D expenditure, life expectancy, prosperity level, Global competitiveness). At the same time Russia did not fall behind in the level of internet development and ICTs, and Russia is catching up the pace on other criteria. Thus, this method defines the problem area and the development directions. 


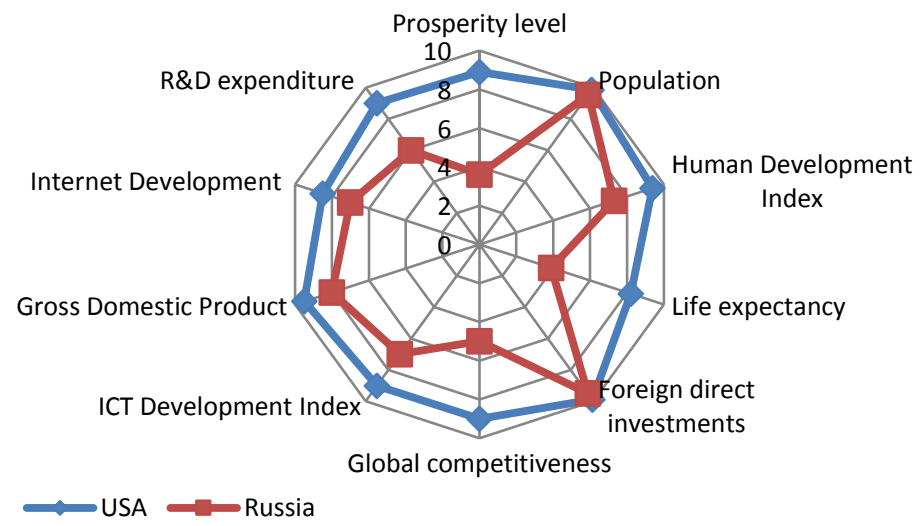

Figure 5. The USA and Russia's competitiveness level, 2015.।

Summarizing, we note that the economic analysis tool demonstrates the state of information confrontation of the USA and Russia, identifies the changes in impact objects, and the effectiveness of used tools and instruments.

\section{References:}

[1] Degterev D.A., Degterev A.H., Game theory and international relations. World Economy and International Relations, No. 2, P. 79-89, 2011.

[2] Janowski A. Cyber security: on what the global companies will spend \$ 76.9 billion. Available at: http://qps.ru/u2UYB, 2014.

[3] Kremer V.V. Cyber-attacks: Trends and Risks. Information security, No. 6, P. 45, 2015.

[4] Krutskikh A.V., Who owns the Internet, he owns the world. International Affairs, No. 11, P. 18-27, 2016.

[5] Meleshkina E.Yu. Political process: main aspects and analysis. Available at: http://qps.ru/c04dg

[6] Security Research Cyber risk Report 2016. Available at: http://qps.ru/gt5Dv

[7] Smirnov F.A. Network warfare in the world economy and international finance. Economic strategies, No. 4, p. 110-119, 2015.

[8] The World Bank. Available at: http://www.worldbank.org 